FEDERAL RESERVE BANK OF SAN FRANCISCO

WORKING PAPER SERIES

\title{
Average Is Good Enough: Average-Inflation Targeting and the ELB
}

\author{
Robert Amano \\ Bank of Canada \\ Stefano Gnocchi \\ Bank of Canada \\ Sylvain Leduc \\ Federal Reserve Bank of San Francisco \\ Joel Wagner \\ Bank of Canada \\ June 2020
}

Working Paper 2020-21

https://www.frbsf.org/economic-research/publications/working-papers/2020/21/

\section{Suggested citation:}

Amano, Robert, Stefano Gnocchi, Sylvain Leduc, Joel Wagner. 2020. “Average Is Good Enough: Average-Inflation Targeting and the ELB," Federal Reserve Bank of San

Francisco Working Paper 2020-21. https://doi.org/10.24148/wp2020-21

The views in this paper are solely the responsibility of the authors and should not be interpreted as reflecting the views of the Federal Reserve Bank of San Francisco or the Board of Governors of the Federal Reserve System. 


\title{
AVERAGE IS GOOD ENOUGH: AVERAGE-INFLATION TARGETING AND THE ELB
}

\author{
ROBERT AMANO, STEFANO GNOCCHI, SYLVAIN LEDUC, AND JOEL WAGNER
}

\begin{abstract}
The Great Recession and current pandemic have focused attention on the constraint on nominal interest rates from the effective lower bound. This has renewed interest in monetary policies that embed makeup strategies, such as price-level or average-inflation targeting. This paper examines the properties of average-inflation targeting in a two-agent New Keynesian (TANK) model in which a fraction of firms have adaptive expectations. We examine the optimal degree of history dependence under average-inflation targeting and find it to be relatively short for business cycle shocks of standard magnitude and duration. In this case, we show that the properties of the economy are quantitatively similar to those under a price-level target.
\end{abstract}

Date: June 24, 2020.

Key words and phrases. ELB, make-up strategies, inflation targeting, price level targeting. JEL classification: E31, E32, E52.

Leduc: Federal Reserve Bank of San Francisco. Email: Sylvain.Leduc@sf.frb.org. Amano: Bank of Canada. Email: bamano@bank-banque-canada.ca. Gnocchi: Bank of Canada. Email: sgnocchi@bankbanque-canada.ca. Wgner: jwagner@bank-banque-canada.ca We benefited from comments by Thomas Mertens and Glenn Rudebusch. Neil Maru and Ian Siqueira provided outstanding research support. The views expressed herein are those of the authors and do not necessarily reflect the views of the Bank of Canada, the Federal Reserve Bank of San Francisco or of the Federal Reserve System. 


\section{INTRODUCTION}

The Great Recession brought greater focus on the constraint that the effective lower bound (ELB) imposes on monetary policy. The current pandemic has sharpened this issue further, as the Federal Reserve once again lowered the federal funds rate to the ELB recently. The decline in the equilibrium real interest rate consistent with full employment and price stability implies a high risk that monetary policy will return to the ELB frequently in the future is high. To address this risk, central banks are now reconsidering their monetary policy frameworks. For instance, in November 2018, the Federal Reserve announced that it would review its strategies, communications, and tools. In particular, policy regimes embedding makeup strategies, such as price-level or average-inflation targeting, are generating renewed interests. These regimes imply that past policy misses must be offset in the future. If these policy responses are credible, the public will then expect them, leading to movements in inflation expectations that facilitate the desired adjustments in the stance of monetary policy.

In this paper, we reconsider the implications of average-inflation targeting in a New Keynesian framework that accounts for the presence of the ELB. We focus on this form of makeup strategy because its minimal departure from current inflation targeting regimes makes it easier to communicate to the public. Given that the benefits of makeup strategies largely derive from their forward-looking nature and the associated effects on expectations, we examine an environment where this channel is appropriately constrained by the presence of two realistic features. In particular, our baseline economy includes a subset of households 
that do not participate in financial markets (see, e.g., Bilbiie (2019)) and in which some firms have adaptive expectations, as in Galí and Gertler (2012). ${ }^{1}$

We focus on average-inflation targeting in the form of implementable rules in economies subject to business cycle shocks of standard magnitude and duration; thus we abstract from more persistent shocks that could lead to long-lasting periods at the ELB, such as that following the 2007 financial crisis. We assume that the policy is credible, so that policymakers are able to commit to a specific rule. In implementing a policy of average-inflation targeting, one important consideration is the size of the time window used to calculate the average inflation rate. In other words, we examine how much history dependence should be embedded in the rule for the policy to be effective. Given the shocks and the frequency, depth, and the average duration of ELB episodes, the degree of history dependence could become very large, making it difficult to distinguish from a price-level targeting rule. In our analysis, we determine the optimal degree of history dependence by maximizing households' welfare subject to the constraints in the economic environment, including the ELB. Depending on the environment, the optimal degree of history dependence incorporates a trade-off between allowing some drift in the price level and providing greater price stability to help manage expectations during ELB episodes.

Overall, for typical-sized shocks, we find that the degree of history dependence is relatively low in our baseline economy. In economies where the ELB binds roughly 10 percent of the time and ELB episodes last four quarters, on average, it is optimal for the central bank to target an average inflation rate calculated over a window of slightly less than two years. In this case, we show that average-inflation targeting leads to outcomes that are very close to

\footnotetext{
${ }^{1}$ See also Del Negro et al. (2013) and MacKay et al. (2013) on the strength of forward guidance in standard DSGE models.
} 
those generated by price-level targeting, with the volatility of inflation and output, as well as welfare, being quantitatively similar under these two policies.

The optimal degree of history dependence in our baseline economy is robust to a few variations in the economic environment. In particular, we show that when the economy is subject to demand shocks, it remains roughly the same if all firms have forward-looking expectations or if there are no hand-to-mouth households. In contrast, the optimal window length declines substantially to about two quarters when the economy is only subject to costpush shocks and firms have adaptive expectations, consistent with findings in Néssen and Vestin (2005). With adaptive expectations, a cost-push shock that increases inflation leads to greater volatility and lower welfare under average-inflation targeting with a long averaging window. This reflects the fact that the policy promises to disinflate the economy without the full stabilizing benefits from lower expected inflation that would arise when all firms form expectations in a forward-looking manner. The optimal average-inflation targeting policy in this case dictates a short window and more drift in the price level. The optimal degree of history dependence is more robust in the case of demand shocks, since they do not entail trade-offs between inflation and output stability.

Our work adds to an important literature on the benefits of makeup strategies at the ELB. For instance, Eggertsson and Woodford (2003) show that the optimal policy at the ELB can be well approximated by a price-level targeting rule, because it introduces history dependence to policy. Reifschneider and Williams (2000) introduce a rule that keeps track of policy shortfalls at the ELB, thus bringing about additional accommodation by keeping policy "lower for longer." It is more directly related to the work of Néssen and Vestin (2005) that compares average-inflation targeting to inflation and price-level targeting. We complement this analysis by focusing on the properties of average-inflation targeting taking 
the ELB into account and by calculating the optimal window's length. In addition, our work complements a recent paper by Mertens and Williams (2019) that looks at makeup strategies, including average-inflation targeting, to tackle the ELB constraint. In addition to considering the Reifschneider and Williams (2000) proposed rule tracking policy shortfalls (i.e., a so-called shadow-rate rule, since it tracks the policy rate that would prevail absent the ELB), Mertens and Williams (2019) also consider a static average-inflation targeting approach. This approach dictates a higher inflation rate during expansions to compensate for lower inflation at the ELB, to generate a specified average inflation rate over the cycle. In addition to a shadow-rate rule, Kiley and Roberts (2017) also examine a policy rule that sets the change in the nominal interest rate as a function of inflation deviations from target and the output gap, such that during ELB episodes policymakers keep the policy rate at the lower bound until inflation rises above target or output rises above potential. Our paper also relates to Svensson (2020), who discusses the properties of a central bank's loss function that includes an average inflation rate as one of its arguments, focusing one an averaging period of fivea years. We complement this work by partly examining the optimal degree of history dependence.

Recently, Bernanke (2017) argued in favor of temporary price-level targeting when monetary policy reaches the ELB. This policy would make up inflation shortfalls from target with above target inflation before lifting the policy rate form the ELB, thus implicitly targeting an average inflation rate during the ELB period. Using the Federal Reserve's FRB/US model to compare the performance of different policy rules, Bernanke et al. (2019) find that temporary price-level targeting with a one- or three-year window lowers the volatility of output and inflation compared to other makeup strategies, such as the shadow-rate rules 
proposed by Reifschneider and Williams (2000) and Kiley and Roberts (2017). Using a similar framework, Hebden and López-Salido (2018) obtain broadly similar results, while also emphasizing that these policies entail risks of large overshoots of the natural rate of unemployment, particularly if the Phillips curve is flat. In contrast, we focus on the costs and benefits of introducing average-inflation targeting at and away from the ELB in small-scale DSGE models.

The remainder of the paper is organized as follows. The next section introduces the economic environment and monetary policy rules considered in our analysis before discussing the calibration of the economy. We then present our main results, focusing on the properties of flexible average-inflation targeting under alternative versions of the model. This last section concludes.

\section{MOdEL}

To examine the effects of different monetary policies, we consider a model that explicitly takes into account the presence of the ELB. In the spirit of Galí and Gertler (2012), Galí et al. (2007), and Bilbiie (2019), we model an economy in which a fraction of households are "hand-to-mouth," in the sense that they fully consume what they earn, and where a fraction of firms have adaptive expectations. These ingredients have been shown to be empirically important for capturing movements in inflation. Given that makeup strategies like averageinflation targeting and price-level targeting work by influencing expectations, the presence of these features may mute their effectiveness and importantly impact the degree of history dependence of average-inflation targeting. The economy faces demand shocks, in the form of shocks to the natural rate of interest, and cost-push shocks. 
III. MODEL

Given the potential merits of average-inflation targeting, we analyze the properties of this monetary policy rule in a canonical new Keynesian model with Calvo pricing and the following two additions: (i) backward-looking price-setting firms following Galí and Gertler (2012), and (ii) hand-to-mouth consumers following the Bilbiie (2019) TANK model. We will start with the household's optimization problem.

III.1. Households. There are a continuum of households between 0 and 1 , where a fraction $(1-\lambda)$ of households are savers $(\mathrm{S})$ and a fraction $\lambda$ live hand-to-mouth $(\mathrm{H})$. For household $j \in\{S, H\}$ the household maximizes its lifetime utility

$$
E_{0} \sum_{t=0}^{\infty} U\left(C_{t}^{j}, N_{t}^{j}\right)
$$

where the period utility function for household $j$ is

$$
U\left(C_{t}^{j}, N_{t}^{j}\right)=\frac{C_{t}^{j^{1-\sigma}}-1}{1-\sigma}-\frac{N_{t}^{j^{1+\psi}}}{1+\psi} .
$$

Here $C_{t}^{j}$ is the composite consumption good consumed by household $j, N_{t}^{j}$ is employment, $\psi$ is the elasticity of labor supply and $\sigma$ is the risk aversion parameter. The consumption $\operatorname{good} C_{t}^{j}$ is defined as

$$
C_{t}^{j} \equiv\left(\int_{0}^{1} C_{t}^{j}(i)^{1-\frac{1}{\epsilon}} d i\right)^{\frac{\epsilon}{\epsilon-1}}
$$

where the consumption good $C_{t}^{j}(i)$ is the amount of good $i$ consumed by household $j$. The elasticity of substitution between different goods is $\epsilon$. 
III.1.1. Savers. Savers maximize their lifetime utility (1) subject to the following budget constraint each period:

$$
\int_{0}^{1} P_{t}(i) C_{t}^{S}(i) d i+Q_{t} B_{t} \leq B_{t-1}+P_{t} W_{t} N_{t}^{S}+D_{t}
$$

where $P_{t}(i)$ is the price of good $i, B_{t}$ is a one-period discount bond with a price $Q_{t}=1 / R_{t}$. $W_{t}$ is real wages and is common across both types of households. Lastly, savers own the firms and receive profits $D_{t}$ each period.

The above optimization problem for savers implies the following first-order conditions for their consumption $C_{t}^{S}$ and labor supply decision $N_{t}^{S}$

$$
\begin{gathered}
1 / R_{t}=\beta E_{t}\left(\left(\frac{C_{t}^{S}}{C_{t+1}^{S}}\right)^{\sigma} \frac{P_{t}}{P_{t+1}}\right) \\
\left(N_{t}^{S}\right)^{\psi}=C_{t}^{S^{-\sigma}} W_{t} .
\end{gathered}
$$

III.1.2. Hand-to-Mouth Households. Hand-to-mouth households are liquidity constrained. As such, they consume their entire income every period and don't purchase bonds. These households maximize their lifetime utility given in equation (1) subject to the following budget constraint each period:

$$
\int_{0}^{1} P_{t}(i) C_{t}^{H}(i) d i=P_{t} W_{t} N_{t}^{H}
$$

The above problem for hand-to-mouth consumers implies the following first-order condition for their labor supply $N_{t}^{H}$ :

$$
\left(N_{t}^{H}\right)^{\psi}=C_{t}^{H^{-\sigma}} W_{t}
$$

Hand-to-mouth households' consumption is determined by their budget constraint

$$
C_{t}^{H}=W_{t} N_{t}^{H}
$$


III.1.3. Aggregate IS curve. To derive the aggregate IS curve, we first take a log-linear approximation of the equilibrium equations, expressing lowercase variables as deviations from their respective steady state. Substituting the wage schedule $w_{t}=(\sigma+\psi) c_{t}$ into the hand-tomouth household budget constraint, we can derive hand-to-mouth consumption as a function of aggregate output $y_{t}$

$$
c_{t}^{H}=\chi y_{t}, \quad \text { where } \chi \equiv 1+\psi \text {. }
$$

With a mass of hand-to-mouth consumers $\lambda$, we can solve for the saver's consumption

$$
c_{t}^{S}=\frac{(1-\lambda \chi)}{(1-\lambda)} y_{t} .
$$

Given the previous two equations, can aggregate across households to obtain the aggregate IS equation:

$$
x_{t}=E_{t} x_{t+1}-\frac{1}{\sigma} \frac{(1-\lambda)}{(1-\lambda \chi)}\left(r_{t}-E_{t} \pi_{t+1}-r_{t}^{n}\right)
$$

where $x_{t}$ is the output gap defined as output deviations from the natural level of output, $y_{t}^{n}$, and where the natural rate of interest, $r_{t}^{n}$, is determined exogenously as

$$
r_{t}^{n}=\left(1-\rho^{r^{n}}\right) \bar{r}^{n}+\rho^{r^{n}} r_{t-1}^{n}+\sigma^{r^{n}} \epsilon_{t}^{r^{n}}
$$

with an autocorrelation coefficient $\rho^{r^{n}}$ and $\sigma^{r^{n}}$ representing the standard deviation of the innovation $\epsilon_{t}^{r^{n}}$.

III.2. Firms. There is a continuum of unit mass firms, with individual firms denoted by $i$. Only a fraction $(1-\theta)$ of firms are able to adjust their price each quarter. Therefore, the aggregate price level is equal to

$$
P_{t}=P_{t-1}^{\theta} \bar{P}_{t}^{*}(1-\theta)
$$


where $\bar{P}_{t}^{*}$ is the reset price index, determined by all firms who reset their prices in that period. Following Gali and Gertler (1999), we assume that a fraction of these firms that reset their price, $\omega \in[0,1)$, are backwards looking, setting prices based a rule-of-thumb rather than setting prices optimally based on expectations. Therefore, the reset price index equals

$$
\bar{P}_{t}^{*}=P_{t}^{f^{(1-\omega)}} P_{t}^{b^{\omega}}
$$

where $P_{t}^{f}$ is the optimal price charged by forward-looking price-setting firms and $P_{t}^{b}$ the price charged by rule-of-thumb price setters. All firms produce output $Y_{t}(i)$ according to the following production function

$$
Y_{t}(i)=N_{t}(i)
$$

where we assume constant returns to scale, with labor as the only input. We have abstracted away from discussing technology shocks in our analysis.

III.2.1. Forward-looking Firms. A fraction of firms $(1-\omega)$ are forward looking and choose $P_{t}^{f}$ to maximizes their profit

$$
\max _{P_{t}^{f}} \sum_{k=0}^{\infty} \theta^{k} E_{t}\left(\Lambda_{t, t+k}\left(\frac{1}{P_{t+k}}\right)\left((1+\tau) P_{t}^{f} Y_{t+k \mid t}-\Phi_{t+k}\left(Y_{t+k \mid t}\right)\right)\right.
$$

given the conditional demand

$$
Y_{t+k \mid t}=\left(\frac{P_{t}^{f}}{P_{t+k}}\right)^{-\epsilon} C_{t+k} .
$$

The stochastic discount factor is $\Lambda_{t, t+k}=\beta^{k} U_{c, t+k}^{S} / U_{c, t}^{S}$, and $\Phi_{t}(\cdot)$ refers to the nominal cost function. $\tau$ is a tax on production to invoke an efficient equilibrium and is set equal to $(\epsilon-1)^{-1}$. It is assumed that the tax on production is returned back to the firm as a lump 
sum. The first-order condition for the forward-looking firm's optimal price $P_{t}^{f}$ is

$$
\sum_{k=0}^{\infty} \theta^{k} E_{t}\left(\Lambda_{t, t+k} Y_{t+k \mid t}\left(\frac{1}{P_{t+k}}\right)\left((1+\tau) P_{t}^{f}-\frac{\epsilon}{\epsilon-1} \Phi_{t+k}^{\prime}\left(Y_{t+k \mid t}\right)\right)=0\right.
$$

III.2.2. Backward-Looking Firms. Backward-looking firms set their prices equal to the previous period's reset price, adjusted by last period's inflation, according to the following rule of thumb

$$
P_{t}^{b}=P_{t-1}^{\bar{*}} \Pi_{t-1}
$$

where $\Pi_{t-1} \equiv \frac{P_{t-1}}{P_{t-2}}$.

III.3. The Phillips Curve. The inclusion of an additional subset of firms that are backward looking implies a hybrid Phillips curve (Galí and Gertler (1999)). After log-linearizing equations (14), (15), (19), and (20), we derive the following Phillips curve with backward-looking firms

$$
\pi_{t}=\chi^{f} \beta E_{t}\left(\pi_{t+1}\right)+\chi^{b} \pi_{t-1}+\kappa x_{t}+u_{t}
$$

so that inflation, $\pi_{t}$, is a function of past and expected inflation with respective weights given by $\chi^{b}=\frac{\omega}{(\omega(1-\theta+\theta \beta)+\theta)}$ and $\chi^{f}=\frac{\theta}{\omega(1-\theta+\theta \beta)+\theta)}$, and of the output gap, $x_{t}$, defined as output deviations from the natural level of output, $y_{t}^{*}$. An exogenous cost-push shock $u_{t}$ is included and evolves according to the following process:

$$
u_{t}=\rho^{u} u_{t-1}+\sigma^{u} \epsilon_{t}^{u}
$$

where $\rho^{u}$ is the persistence and $\sigma^{u}$ is the standard deviation of the innovation $\epsilon_{t}^{u}$.

The slope of the Phillips curve is given by

$$
\kappa=\frac{(1-\omega)(1-\theta)(1-\theta \beta)}{(\omega(1-\theta+\theta \beta)+\theta)}(\sigma+\psi)
$$


so that the slope collapses to the typical expression, $\frac{(1-\theta)(1-\theta \beta)}{\theta}(\sigma+\psi)$, when all firms have forward-looking expectations $(\omega=0)$.

III.4. Monetary Policy. We consider three alternative monetary policy frameworks, including an inflation-targeting rule

$$
r_{t}=\bar{r}+\phi^{\pi} \pi_{t}+\phi^{x} x_{t}
$$

a price-level targeting rule

$$
r_{t}=\bar{r}+\phi^{p} p_{t}+\phi^{x} x_{t}
$$

and an average-inflation targeting rule

$$
r_{t}=\bar{r}+\frac{\phi^{\pi}}{m} \sum_{k=0}^{m} \pi_{t-k}+\phi^{x} x_{t}
$$

where $m$ denotes the number of lags included when calculating average inflation. As a robustness exercise, we also consider a broader rule that includes expected inflation terms.

III.5. Equilibrium. Clearing in the labor market implies

$$
N_{t}=\lambda N_{t}^{H}+(1-\lambda) N_{t}^{S}
$$

where aggregate employment across all $i$ firms is given as

$$
N_{t}=\int_{0}^{1} N_{t}(i) d i
$$

Equilibrium in the goods market implies

$$
Y_{t}=C_{t}=\lambda C_{t}^{H}+(1-\lambda) C_{t}^{S}
$$

Table 1 provides a summary of the model's equilibrium conditions. 


\section{Calibration}

Table 2 summarizes the calibration of the benchmark model with backward-looking firms and hand-to-mouth consumers. Starting with the household, we assume an elasticity of labor supply, $\psi$, of 1 and a constant risk aversion parameter, $\sigma$, of 1 , implying logarithmic preference. The household's discount factor $\beta$ will be set equal to 0.994 , implying a steady-state interest rate of 2.4percent. With limited asset market participation, there is one additional parameter $\lambda$, which determines the fraction of hand-to-mouth consumers. In our calibration, we assume 20percent of the population lives hand-to-mouth with $\lambda=0.2$.

For the firms, we set the probability that a firm is unable to adjust prices each quarter, $\theta$, to 0.7 , which implies that prices are fixed on average for four quarters. The elasticity of substitution across goods, $\epsilon$, will be set equal to 5, implying a markup of 1.25 . With backward-looking firms, we set $\omega=0.75$. Under this calibration the coefficients for lagged inflation $\left(\chi^{b}\right)$ and expected inflation next quarter $\left(\chi^{f}\right)$ in equation (21) are 0.52 and 0.48 respectively.

As for the calibration for the three policy rules, we consider an average-inflation targeting policy rule with up to 15 lags. For each policy, we set the weights on the target $\left(\phi^{\pi}\right.$ and $\left.\phi^{P}\right)$ equal to 1.5, where we assume no interest rate smoothing nor any weight on the output gap. Lastly, there are two shocks in the model; a demand shock and a cost-push shock. Following Guerrieri and Iacoviello (2014), each shock will follow an AR(1) process with a persistence of 0.6 and standard deviation of 0.0067 .

\section{RESUlts}

In this section, we examine the performance of average-inflation targeting relative to a simple Taylor rule or policies that target either the current or expected inflation rate or the 
price level. As a reference point, we also compute the optimal policy under commitment. Using model simulations, we first examine the optimal degree of history dependence under average-inflation targeting in our benchmark economy and a few alternative specifications: (i) Ricardian households and all firms set expectations in a forward-looking manner (the standard New Keynesian framework), (ii) Ricardian households and a fraction of firms have backward-looking expectations (the Gali-Gertler framework), and (iii) hand-to-mouth consumers and all firms set expectations in a forward-looking manner (a TANK framework). We solve the model numerically using the algorithm developed in Guerrieri and Iacoviello (2015), which uses a first-order perturbation approach applied in a piecewise fashion to environments with occasionally binding constraints.

To compare our results with the literature, we first focus on cost-push shocks, abstracting from the ELB. We then introduce the ELB constraint and focus on demand shocks, as they are more relevant for the challenges that the constraint imposes on monetary policy. ${ }^{2}$ We contrast the impact of the policies on household welfare and on the volatility of the economy. Throughout, we examine the extent to which average-inflation targeting, under the optimal degree of history dependence, can approximate the properties of the economy under price-level targeting.

V.1. The Optimal Degree of History Dependence. We first look at the optimal degree of history dependence under average-inflation targeting under commitment for our benchmark economy and the alternative models. For this analysis, we assume that the coefficients on inflation and the output gap in the interest-rate rules remain fixed. We calculate the optimal degree of history dependence by varying the window's length, $k$, in the average-inflation

\footnotetext{
${ }^{2}$ While a negative cost-push shock could move the policy rate to the ELB, it would be accompanied by higher output.
} 
targeting rule to maximize households' welfare. We conduct this exercise by simulating the economy for 10,000 periods.

Table 3 reports the optimal averaging window length, assuming that interest rates are above the ELB and that only cost-push shocks impact the economy. We find that the optimal degree of history dependence in the benchmark economy is only two quarters. The size of the averaging window is robust to abstracting from the presence of hand-to-mouth consumers. However, this small degree of history dependence is largely due to the presence of firms with backward-looking expectations. It is instead optimal to include eight quarters when calculating the average inflation rate when all firms have forward-looking expectations. As shown in the literature (e.g., Néssen and Vestin (2005)), makeup strategies, including average-inflation targeting, can be costly in responding to cost-push shocks under adaptive expectations. For instance, following a positive cost-push shock that increases inflation, average-inflation targeting with a long averaging window promises to disinflate the economy without the full stabilizing benefits from lower expected inflation that would arise when all firms form expectations in a forward-looking manner. As a result, the policy increases output volatility, which is costly in terms of welfare. The optimized average-inflation targeting policy in this case dictates a short window and more drift in the price level.

However, this intuition doesn't carry through to demand shocks. The top panel of Table 4 shows that the optimal window length of roughly five quarters is stable across all model variations, including environments where some firms have adaptive expectations. By inducing history dependence, makeup strategies are closer to the optimal monetary policy under commitment in the canonical baseline New Keynesian framework, which displays policy persistence (Woodford (1999)). Since demand shocks do not entail a trade-off between inflation 
and output stabilization, the size of the averaging window is robust to adaptive expectations. It is similarly robust to varying the degree of hand-to-mouth households.

In contrast, the optimal degree of history dependence importantly hinges on the inflation weight in the interest-rate rule. Figure 1 shows that the optimal size of the averaging window is inversely related to that weight. ${ }^{3}$

Average-inflation targeting and the ELB. We now introduce the ELB in our analysis. We concentrate on demand shocks, since cost-push shocks do not capture the challenges imposed by a weak economy with low inflation at the ELB.

The bottom panel of Table 4 reports that taking into account the ELB increases the optimal degree of history dependence, with the magnitude of this effect being slightly more pronounced when all firms have forward-looking expectations. Across the different model specifications, the optimal size of the averaging window is between six and seven quarters. In the presence of the ELB, a higher degree of history dependence is welfare enhancing, since it introduces needed policy accommodation through expectations of a lower-for-longer policy stance. While the monetary policy rules in our baseline model do not directly respond to economic activity, assuming that policymakers put some weight (i.e., $\phi^{x}=0.5$ ) on the output gap does not change the width of the optimal window, as shown in Table 5 .

To highlight this channel, we compare the behavior of the economy under average-inflation targeting and a few alternative policies following a negative demand shock that pushes the economy to the ELB. In particular, we consider a simple Taylor rule, price-level targeting, and the optimal policy under commitment. As shown in Figure 2, output and inflation decline substantially more when monetary policy is governed by the Taylor rule. The policy rate lifts

\footnotetext{
${ }^{3}$ Note that there is a unique stable local equilibrium even when the weight on inflation is less than 1 , as long as there is a sufficient degree of history dependence.
} 
off from the ELB after four quarters, as output recovers and the disinflationary pressures diminish. In contrast, the movements in output and inflation are much more muted under the optimal policy. Output declines less than half as much and inflation falls only slightly before overshooting the target for several quarters. Compared to price-level targeting or the optimized average-inflation targeting rule, the optimal policy lowers the policy rate sooner and for a prolonged period. The economy's response under the price-level targeting rule is qualitatively similar to that under the optimal policy, although output and inflation decline more. average-inflation targeting with an optimal window length of six quarters leads to output and inflation outcomes that are close to those under price-level targeting.

The similarity between these two policies can also be seen more comprehensively in Figure 3 , which reports the volatility of inflation and output against the volatility of the interest rate, thus facilitating comparison across policies. Using the benchmark economy, we derive this figure by varying the weight on inflation (or the price level) in the interest-rate rules. The figure shows that the standard deviation of inflation and output decline, because monetary policy becomes more responsive to price pressures and interest rates become more volatile. The decline in both inflation and output volatility reflects the absence of stabilization tradeoffs under demand shocks. Importantly, the figure shows that the properties of price-level targeting can be well approximated by average-inflation targeting with a relatively short averaging window. For a given volatility of interest rates, the volatility of inflation and output under average-inflation targeting or price-level targeting are quantitatively similar and substantially lower than under the Taylor rule. In addition, as shown in Table 6, welfare is only slightly lower under average-inflation targeting than price-level targeting. 


\section{CONCLUSion}

In this paper, we reconsidered the implications of average-inflation targeting in a New Keynesian framework that accounts for the presence of the ELB. Given that the benefits of makeup strategies largely derive from their forward-looking nature and the associated effects on expectations, we examined an environment in which this channel is constrained by adaptive expectations and financial market imperfections. We focused on average-inflation targeting in the form of implementable rules and found that the degree of history dependence is relatively low in our baseline economy. In most cases, it is optimal for the central bank to target an average inflation rate calculated over a window of slightly less than two years, yielding outcomes that are very close to those generated by price-level targeting. 


\section{REFERENCES}

Bernanke, B. S. (2017). Monetary policy in a new era. Brookings. Available at https://www.brookings.edu/wp-content/uploads/2017/10/bernanke_ rethinking_macro_final.pdf as of May 5, 2020.

Bernanke, B. S., Kiley, M. T., and Roberts, J. M. (2019). Monetary policy strategies for a low-rate environment. American Economic Review Papers $\&$ Proceedings, 109:421-426.

Bilbiie, F. O. (2019). Monetary policy and heterogeneity: An analytical framework. Mimeo. Available at https://docs.google.com/viewer?a=v\&pid=sites\&srcid= ZGVmYXVsdGRvbWFpbnxmbG 9yaW5iaWxiaWl l fGd 40 jNkMThh z jcyNDU 4MzY2ODQ as of May 5, 2020.

Del Negro, M., Giannoni, M., and Patterson, C. (2013). The forward guidance puzzle. Federal reserve bank of new york staff report 574 .

Eggertsson, G. B. and Woodford, M. (2003). The zero bound on interest rates and optimal monetary policy. Brookings Papers on Economic Activity, 34(1):139-235.

Galí, J. and Gertler, M. (2012). Inflation dynamics: A structural econometric analysis. Journal of Monetary Economics, 44:195-222.

Galí, J., López-Salido, D., and Vallés, J. (2007). Understanding the effects of government spending on consumption. Journal of the European Economic Association, 5(1):227-270.

Guerrieri, L. and Iacoviello, M. (2015). Occbin: A toolkit for solving dynamic models with occasionally binding constraints easily. Journal of Monetary Economics, 70:22-38.

Hebden, J. and López-Salido, D. (2018). From taylor's rule to bernanke's temporary price level targeting. Finance and economics discussion series 2018-051. Available at https: //doi.org/10.17016/FEDS.2018.051. as of May 5, 2020. 
Kiley, M. T. and Roberts, J. M. (2017). Monetary policy in a low interest rate world. Brookings Papers on Economic Activity, pages 317-72.

MacKay, A., Nakamura, E., and Steinsso, J. (2013). The power of forward guidance revisited. American Economic Review, 106(10):3133-3158.

Mertens, T. and Williams, J. C. (2019). Tying down the anchor: Monetary policy rules and the lower bound on interest rates. Federal Reserve Bank of San Francisco Working Paper Series 14. Available at https://www.frbsf.org/economic-research/files/ wp2019-14.pdf as of May 5, 2020.

Néssen, M. and Vestin, D. (2005). Average inflation targeting. Journal of Money, Credit and Banking, 37(5):837-863.

Reifschneider, D. and Williams, J. (2000). Three lessons for monetary policy in a low-inflation era. Journal of Money, Credit and Banking, 32:936-66.

Svensson, L. E. O. (2020). Monetary policy strategies for the federal reserve. International Journal of Central Banking, 16(1):133-193.

Woodford, M. (1999). Optimal policy inertia. NBER Working Paper 7261. 
TABLE 1. Summary of equilibrium conditions

Summary

FOC $C_{t}^{S}$

FOC $N_{t}^{S}$

Budget constraint S

FOC $N_{t}^{H}$

Budget constraint $\mathrm{H}$

Labour market clearing

Goods market clearing

Aggregate consumption

Firm production

Marginal costs

FOC for $p_{t}^{f}$

Rule-of-thumb price setters

Aggregate price level

Reset price

Aggregate IS curve

Phillips curve

Monetary policy rule
Nonlinearized

$$
1 / R_{t}=\beta E_{t}\left(\left(\frac{C_{t}^{S}}{C_{t+1}^{S}}\right)^{\sigma} \frac{P_{t}}{P_{t+1}}\right)
$$$$
\left(N_{t}^{S}\right)^{\psi}=C_{t}^{S^{-\sigma}} W_{t}
$$

$C_{t}^{S}=W_{t} N_{t}^{S}+D_{t}$

$\left(N_{t}^{H}\right)^{\psi}=C_{t}^{H^{-\sigma}} W_{t}$

$C_{t}^{H}=W_{t} N_{t}^{H}$

$N_{t}=\lambda N_{t}^{H}+(1-\lambda) N_{t}^{S}$

$C_{t}=Y_{t}$

$C_{t}=\lambda C_{t}^{H}+(1-\lambda) C_{t}^{S}$

$Y_{t}=N_{t}$

$\Phi_{t}=P_{t} W_{t}$

$\sum_{k=0}^{\infty} \theta^{k} E_{t}\left(\Lambda_{t, t+k} Y_{t+k \mid t}\left(\frac{1}{P_{t+k}}\right)\left((1+\tau) P_{t}^{f}-\frac{\epsilon}{\epsilon-1} \Phi_{t+k}^{\prime}\left(Y_{t+k \mid t}\right)\right)=0\right.$

$P_{t}^{b}=\bar{P}_{t-1}^{*} \Pi_{t-1}$

$P_{t}=P_{t-1}{ }^{\theta} \bar{P}_{t}^{*}(1-\theta)$

$\bar{P}_{t}^{*}=P_{t}^{f^{(1-\omega)}} P_{t}^{b^{\omega}}$

$\frac{1}{1+\left(r_{t}-r_{t}^{n}\right)}=\beta E_{t}\left(\left(\frac{X_{t}}{X_{t+1}}\right)^{\sigma \frac{(1-\lambda \chi)}{(1-\lambda)}} \frac{P_{t}}{P_{t+1}}\right)$

$\Pi_{t}=E_{t}\left(\Pi_{t+1}^{\chi^{f} \beta}\right) \Pi_{t-1} \chi^{b} X_{t}^{\kappa} u_{t}$

varied 
TABle 2. Calibration of the Benchmark Model

$\beta \quad$ Discount factor $\quad 0.994$

$\sigma \quad$ Inverse intertemporal elasticity $\quad 1.00$

$\psi \quad$ Frisch elasticity $\quad 1.00$

$\theta \quad$ Calvo price adjustment probability $\quad 0.70$

$\epsilon \quad$ Elasticity of substitution $\quad 5$

$\phi^{\pi} \quad$ Weight on inflation targets $\quad 1.50$

$\phi^{P} \quad$ Weight on price level target $\quad 1.50$

$\phi^{x} \quad$ Weight on the output gap 0

$\rho^{r n} \quad$ Persistence of demand shock $\quad 0.60$

$\rho^{u u} \quad$ Persistence of cost-push shock $\quad 0.60$

$\sigma^{r n} \quad$ Standard deviation of demand shock $\quad 0.0067$

$\sigma^{u u} \quad$ Standard deviation of cost-push shock 0.0067

$\omega \quad$ Fraction of backward-looking firms $\quad 0.75$

$\lambda \quad$ Fraction of hand-to-mouth consumers $\quad 0.2$ 
TABLE 3. The Optimal Degree of History Dependence: Cost-Push Shocks

$\left.\begin{array}{|c|c|}\hline \text { Model } & \begin{array}{c}\text { Optimal } \\ \text { Width }\end{array} \\ \hline \begin{array}{c}\text { Benchmark Model } \\ \left(\omega=0.75, \lambda^{H}=0.2\right)\end{array} & 2 \\ \text { Hand-to-Mouth Consumer } \\ \left(\omega=0, \lambda^{H}=0.2\right) \\ \text { Backwards Looking Firms } \\ \left(\omega=0.75, \lambda^{H}=0\right) \\ \text { Baseline New Keynesian } \\ \left(\omega=0, \lambda^{H}=0\right)\end{array}\right)$


TABle 4. The Optimal Degree of History Dependence: Demand Shocks

\begin{tabular}{|c|c|}
\hline Model & $\begin{array}{l}\text { Optimal } \\
\text { Width }\end{array}$ \\
\hline Without Zero Lower Bound & \\
\hline $\begin{array}{l}\text { Benchmark Model } \\
\qquad\left(\omega=0.75, \lambda^{H}=0.2\right)\end{array}$ & 5 \\
\hline $\begin{array}{l}\text { Hand-to-Mouth Consumer } \\
\qquad\left(\omega=0, \lambda^{H}=0.2\right)\end{array}$ & 4 \\
\hline $\begin{array}{c}\text { Backwards Looking Firms } \\
\quad\left(\omega=0.75, \lambda^{H}=0\right)\end{array}$ & 5 \\
\hline $\begin{array}{c}\text { Baseline New Keynesian } \\
\left(\omega=0, \lambda^{H}=0\right)\end{array}$ & 5 \\
\hline With Zero Lower Bound & \\
\hline $\begin{array}{l}\text { Benchmark Model } \\
\qquad\left(\omega=0.75, \lambda^{H}=0.2\right)\end{array}$ & 6 \\
\hline $\begin{array}{c}\text { Hand-to-Mouth Consumer } \\
\qquad\left(\omega=0, \lambda^{H}=0.2\right)\end{array}$ & 7 \\
\hline $\begin{array}{c}\text { Backwards Looking Firms } \\
\quad\left(\omega=0.75, \lambda^{H}=0\right)\end{array}$ & 6 \\
\hline $\begin{array}{c}\text { Baseline New Keynesian } \\
\quad\left(\omega=0, \lambda^{H}=0\right)\end{array}$ & 7 \\
\hline
\end{tabular}


TABle 5. The Optimal Degree of History Dependence: Demand Shocks and

\section{Output Gaps}

\begin{tabular}{|c|c|c|}
\hline Model & $\begin{array}{c}\text { Optimal Width } \\
\text { Weight on Output Gap, } \\
\phi^{x}=0\end{array}$ & $\begin{array}{c}\text { Optimal Width } \\
\text { Weight on Output Gap, } \\
\phi^{x}=0.5\end{array}$ \\
\hline $\begin{array}{c}\text { Benchmark Model } \\
\left(\omega=0.75, \lambda^{H}=0.2\right)\end{array}$ & 6 & 6 \\
$\begin{array}{c}\text { Hand-to-Mouth Consumer } \\
\left(\omega=0, \lambda^{H}=0.2\right)\end{array}$ & 7 & 7 \\
$\begin{array}{c}\text { Backwards Looking Firms } \\
\left(\omega=0.75, \lambda^{H}=0\right)\end{array}$ & 6 & 6 \\
Baseline New Keynesian \\
$\left(\omega=0, \lambda^{H}=0\right)$
\end{tabular}


TABle 6. Welfare

$\left.\begin{array}{|c|c|}\hline \text { Model } & \begin{array}{c}\text { Optimal } \\ \text { window } \\ \text { (quarters) }\end{array} \\ \hline \begin{array}{c}\text { Benchmark model } \\ \left(\omega=0.75, \lambda^{H}=0.2\right)\end{array} & 2 \\ \text { Hand-to-mouth consumers } \\ \left(\omega=0, \lambda^{H}=0.2\right) \\ \text { Backward-looking firms } \\ \left(\omega=0.75, \lambda^{H}=0\right) & 8 \\ \text { Baseline New Keynesian } \\ \left(\omega=0, \lambda^{H}=0\right)\end{array}\right)$


Figure 1. The Optimal Window Length and the Weight on Inflation in the Rule

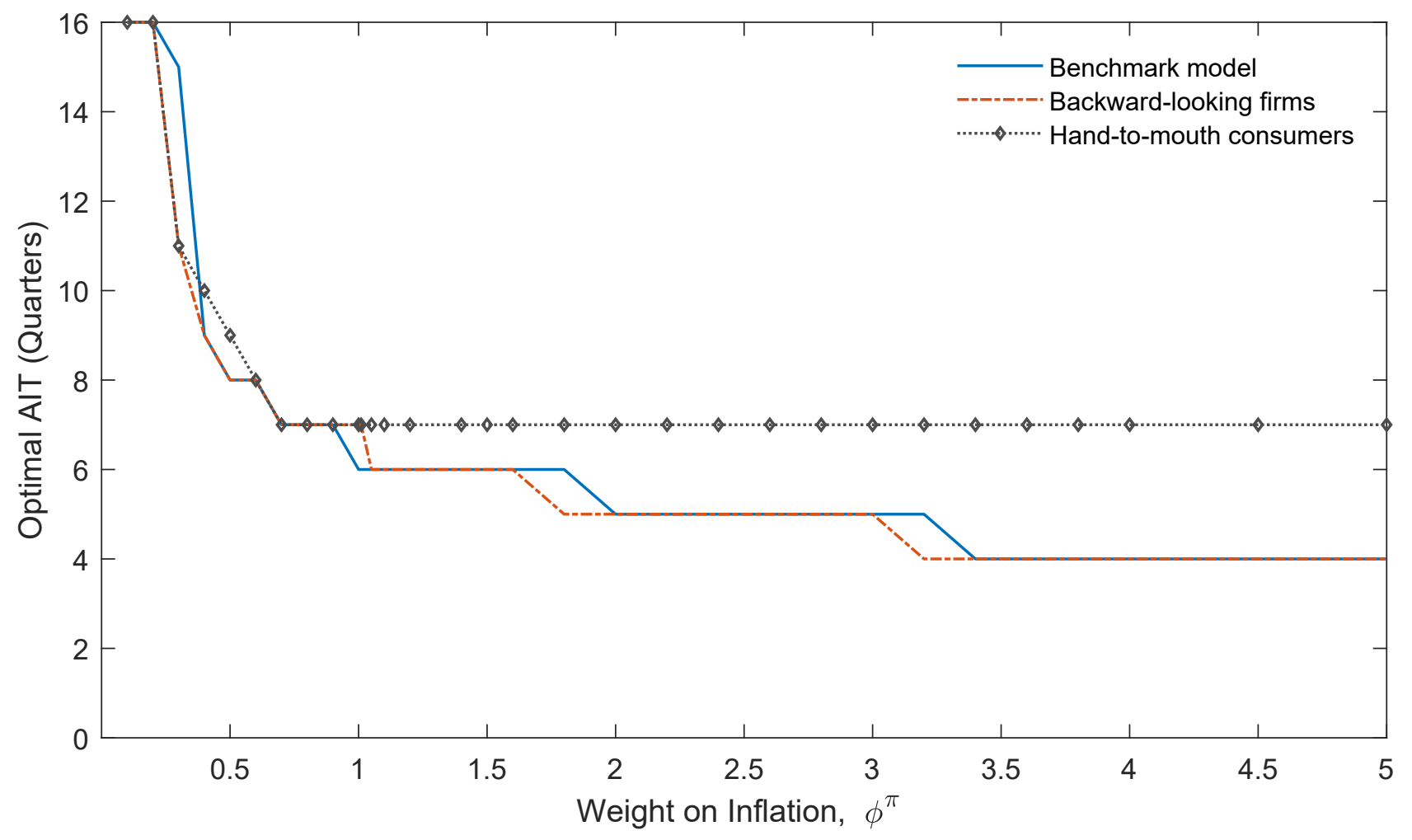



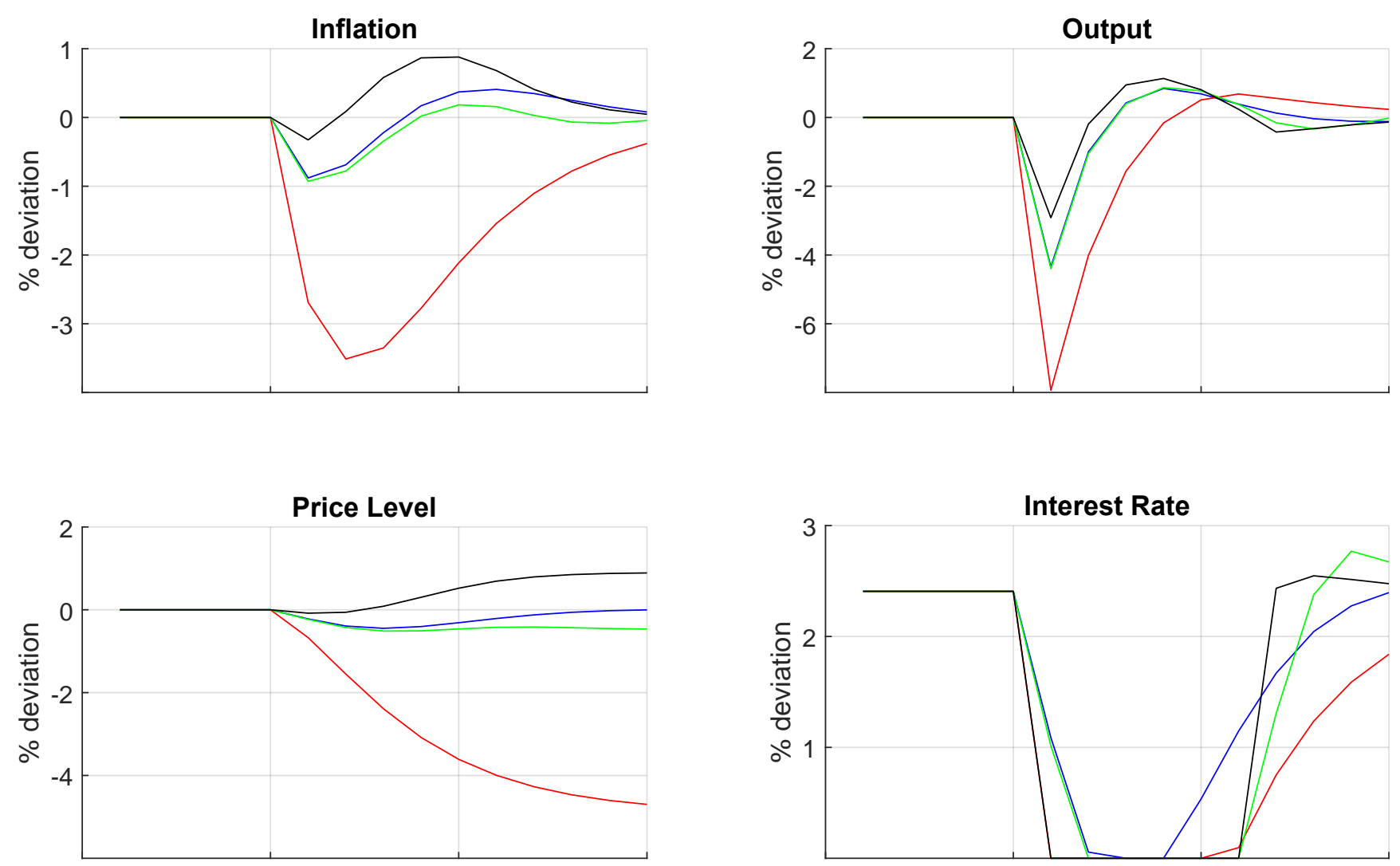
Figure 3. Output and Inflation Volatility under Alternative Policies
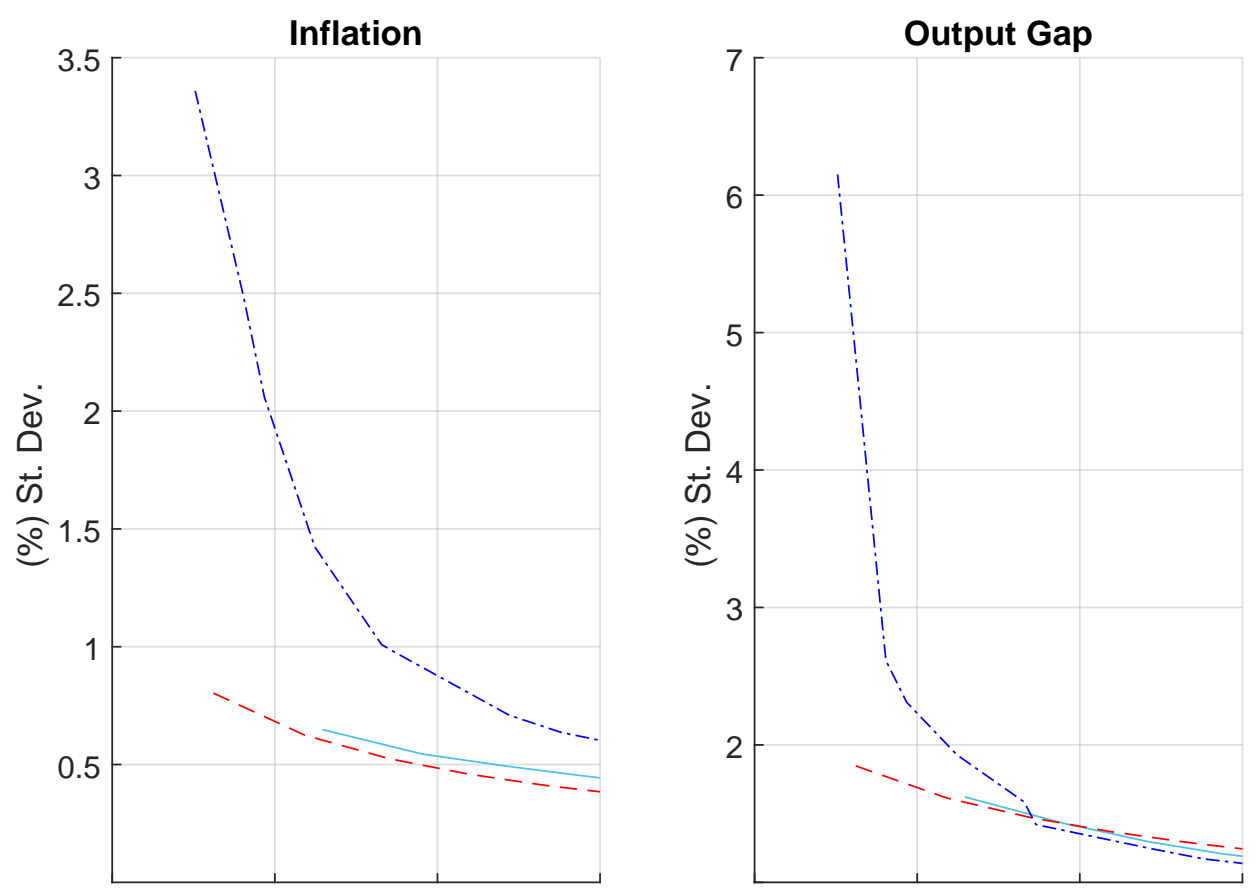

Optimized average-inflation targeting

Price-level targeting

Inflation targeting 